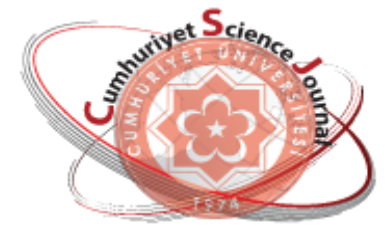

e-ISSN: 2587-246X

ISSN: $2587-2680$

\section{Cundenory at Seionce Journal esJ}

Cumhuriyet Sci. J., Vol.40-2(2019) 527-535

\title{
Evaluation of NCEP/NCAR Reanalysis Precipitable Water Data Comparing to Radiosonde Observations for Turkey
}

\author{
$\operatorname{Elçin} \operatorname{TAN}^{1, *}(\mathbb{D})$ \\ ${ }^{1}$ Istanbul Technical University, Aeronautics and Astronautics Faculty, Department of Meteorological Engineering, \\ Maslak, Istanbul / TURKEY
}

Received: 11.02.2018; Accepted: 17.05.2019

http://dx.doi.org/10.17776/csj.393237

\begin{abstract}
Precipitable Water (PW) data of NCEP/NCAR Reanalysis Project (NNRP) model is evaluated by comparing to radiosonde data obtained from 8 locations of Turkey for the years between 2015 and 2017. Two methods are utilized to extract NNRP data for the observation locations. In the first method, the nearest NNRP grid point to the radiosonde locations is selected. The second method is the application of bilinear interpolation method on NNRP data to include the weighted effects of corresponding grid locations related with the observation sites. Both NNRP and radiosonde data have $12 \mathrm{~h}$ interval for the times $0000 \mathrm{Z}$ and $1200 \mathrm{Z}$. PW output of NNRP model is compared to observations by means of graphical evaluation of time series, error analyses (Mean Absolute Error (MAE), Root Mean Square Error (RMSE), and Root Mean Squared Error (nRMSE)), goodness of fit tests (Cp and PBIAS), and probability density functions (PDF). Error analyses of most of the observation locations indicate that bilinear interpolation method is better than utilizing the nearest grid value data which is not obtained by applying any interpolation technique. Error analyses indicate that nRMSEs of NNRP data for PW analyses are less than 10\% for 6 locations of Turkey (Ankara, Diyarbakir, Erzurum, Isparta, Istanbul, and Izmir) if it is assumed that the observations have no errors for the years between 2015 and 2017. nRMSEs of the other 2 coastal locations (Adana and Samsun) are the same as $13.8 \%$ and this may indicate that local moisture sources of these locations are greater than mesoscale moisture fields, since NNRP data may not capture local effects well due to its spatial resolution. Comparisons of probability density functions (PDF) of these data sets show that NNRP model may not be successful in capturing extreme values.
\end{abstract}

Keywords: NCEP/NCAR Reanalysis Data Project, Precipitable Water, normalized Root Mean Square Error.

\section{NCEP/NCAR Modelinin Yağışa Geçebilir Su Buharı Miktarındaki Başarısının Türkiye'deki Radyosonda (Radyozonde) Gözlemleri ile Karşılaştırılarak Değerlendirilmesi}

\footnotetext{
Özet. NCEP/NCAR Reanaliz Projesi (NNRP) modelinin yağışa geçebilir su buharı miktarı verileri, Türkiye'nin 8 istasyonundan alınan radyosonde verileriyle 2015-2017 yılları için karşılaştırılarak değerlendirilmiştir. NNRP verilerinden gözlem noktalarına karşılık gelen zaman serilerini oluşturabilmek için iki yöntem kullanılmıştır. İlk yöntemde ilgili istasyona en yakın grid noktasından zaman serisi oluşturulmuştur. İkinci yöntem ise, istasyon konumuna yakın olan grid noktalarının ağırlıklı etkilerini dikkate alabilmek için bilinear interpolasyon yönteminin NNRP verilerine uygulanmasıdır. NNRP ve radyosonda verilerinin zaman aralığı, $0000 \mathrm{Z}$ ve 1200 Z saatleri için, 12 saattir. NNRP modelinin PW çıktısı gözlemlerle karşılaştırılırken zaman serileri grafiksel olarak değerlendirilmiş, hata analizleri (Ortalama Mutlak Hata (MAE), Kök Ortalama Kare Hata (RMSE) ve Kök Ortalama Kare Hata (nRMSE)) yapılmış, uygunluk test sonuçları (Cp ve PBIAS) belirlenmiş ve olasılık
} 
yoğunluk fonksiyonları (PDF) grafiklendirilmiştir. İstasyonların çoğunun hata analizi, bilinear enterpolasyon yönteminin, bir interpolasyon tekniği uygulamadan seçilen en yakın grid noktasının değerlerinden daha uygulanabilir olduğunu göstermektedir. Gözlemlerin hata içermediği kabulü ile, NNRP verilerinin nRMSE'lerinin, Türkiye'nin 6 istasyonu için (Ankara, Diyarbakır, Erzurum, Isparta, İstanbul ve İzmir) \%10'dan az olduğu belirlenmiştir. Kıyıya yakın olan diğer 2 istasyon (Adana ve Samsun) için de nRMSE \%13.8'dir. Bu sonuçlar, çözünürlüğünün düşük olmasından dolayı NNRP modelinin lokal nem etkilerini doğru kestiremediğini göstermektedir. Olasılık yoğunluk fonksiyonlarının (PDF) karşılaştırmaları ise NNRP modelinin aşırı değerleri yakalamadaki başarısının düşük olduğunu belirtmektedir.

Anahtar Kelimeler: NCEP/NCAR Reanaliz Veri Projesi, Yă̆ışa Geçebilir Su Buharı Miktarı, standartlaştırılmış Karekök Ortalama Hata Karesi.

\section{INTRODUCTION}

Precipitable water is the column integrated atmospheric water vapor and it has closely correlated with precipitation [1]. Although precipitation is an output of numerical weather prediction models (NWP) and this output can be compared with rain gauge precipitation observations, precipitable water might be a better indicator than precipitation for the studies related to dynamical modeling of atmospheric moisture for several reasons. One of those reasons is that atmospheric moisture, as relative humidity and mixing ratio/specific humidity, can be both initial/boundary conditions and output of NWP models, respectively, where precipitation is an output of them only. Another reason is that microphysical processes are large sources of complexity in NWP models and this may affect the accuracy of precipitation output of these models than that of moisture fields. Thus, this study focuses on precipitable water evaluation of NCEP/NCAR Reanalysis Project (NNRP) Model [2] data for Turkey.

NNRP data have been widely evaluated for precipitable water in several studies [3-7] and their discussions mostly indicate that NNRP data should be evaluated for the specific locations before performing the studies, because the uncertainties of NNRP Model may vary depending on whether the assimilation techniques were applied for the corresponding locations [8]. For Turkey, recent studies utilized with NCEP/NCAR Reanalysis Project (NNRP) Data are mostly for downscaling or comparison purposes in climate studies [9-11]. However, especially for precipitable water, the performance of the dataset itself has not verified for
Turkey, yet. Therefore, as a first attempt, this study aims to verify the precipitable water accuracy of NNRP Dataset for Turkey to quantify the possible errors of the model. Consequently, determination of these residuals might help to understand implicitly added error sources to these data.

In the following section, data sets and the methods used for this study are explained, in detail. In Section 3, comparisons of NNRP precipitable water and radiosonde data are presented by means of visual inspections of time series, error analyses including goodness of fit tests and probability density functions for 8 observation stations. Section 4 concludes the study with suggestions for future work.

\section{MATERIALS AND METHODS}

\subsection{Data}

Precipitable water data of 12-hourly NCEP/NCAR Global Reanalysis Model [2] are evaluated for Turkey. The NCEP/NCAR Reanalysis Project dataset (NNRP) has $2.5^{\circ} \times 2.5^{\circ}$ horizontal resolutions with 28 vertical sigma levels. NNRP is provided by the Research Data Archive (RDA) of the University Corporation for Atmospheric Research (UCAR) [12]. The grid locations of NNRP dataset are presented in Figure 1 with blue markers.

Precipitable water data calculated by using radiosonde observations of 8 locations in Turkey are also utilized to verify NNRP dataset. The precipitable water data is obtained from University of Wyoming [13] for the years between 2015 and 
2017. The locations and names of observation stations are indicated with red markers in Figure 1. Both NNRP and radiosonde data have $12 \mathrm{~h}$ interval

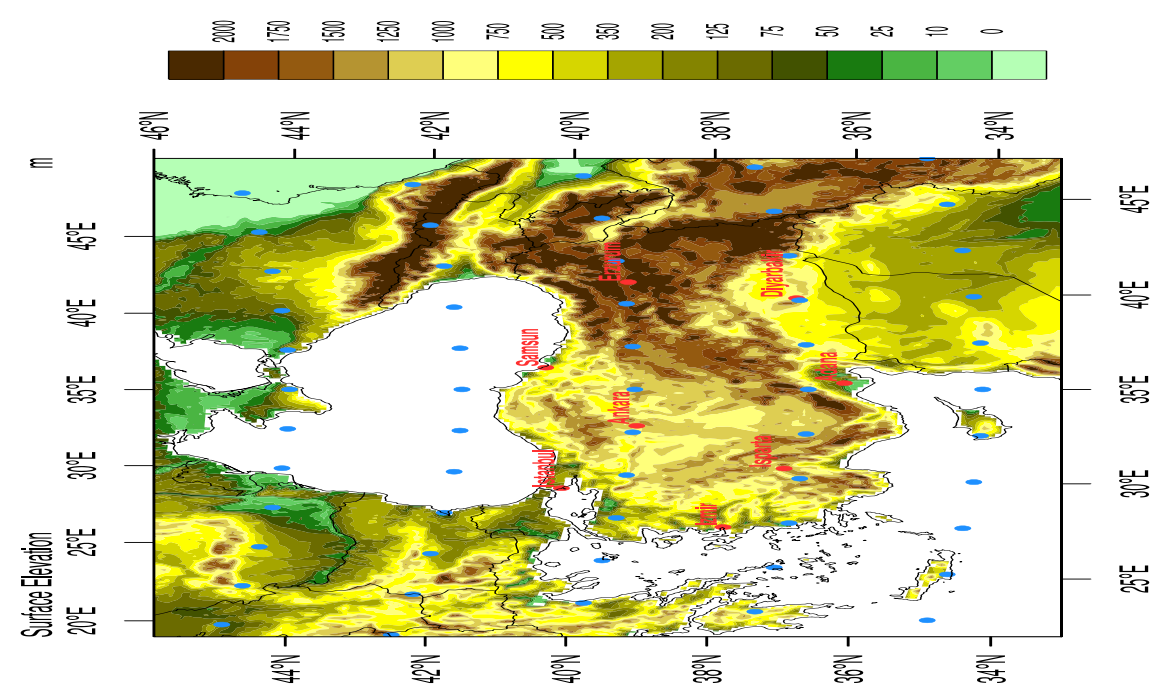

Figure 1. Surface elevation map of Turkey with the locations of 8 radiosonde stations of Turkey (red) and grid-point locations of NNRP data set (blue).

As seen in Figure 1, Turkey has a complex topography and therefore spatial variation of moisture may change abruptly. Moisture rates of Adana and Samsun are highest; rates of Istanbul (Kartal) and Izmir are moderate, and Ankara, Erzurum, Isparta, and Diyarbakir has lower rates comparing to the studied 8 station locations [14].

\subsection{Methods}

Construction of NNRP time series for the corresponding 8 radiosonde locations of Turkey is performed by using two methods. One is to select the nearest grid point of NNRP data with respect to the corresponding radiosonde location without applying any interpolation method. The other is to apply bilinear interpolation method to NNRP data to construct corresponding time series at the observation locations.

First of all, time series of the NNRP dataset and observations are plotted for a visual inspection starting from January 2015 to December 2017. Then, Goodness of Fit (GoF) tests, including error analyses, are calculated to evaluate the performance of NCEP/NCAR Global Reanalysis Model with respect to precipitable water (PW) radiosonde observations for the same time span. These tests, which are performed by utilizing hydroGOF-package in $\mathrm{R}$, include Coefficient of for the times $0000 \mathrm{Z}$ and $1200 \mathrm{Z}$ starting from January 1, 2015 to December 31, 2017.
Persistence (cp), Mean Absolute Error (MAE), Root Mean Squared Error (RMSE), Normalized Root Mean Squared Error (nRMSE), and Percentage bias (PBIAS). Equations of the corresponding tests can be found in the manual of this package [15]. Finally, probable density functions are constructed for further evaluations.

\section{RESULTS AND DISCUSSION}

Error analyses of two methods indicate that bilinear interpolation method is better than choosing the nearest grid point approach, especially for the coastal sites. Table 1 presents the error differences of both bilinear method (indicated by the column named "Bilinear") and the nearest grid point selection method (indicated by the column named "Nearest"). For instance, the comparisons of Istanbul seem reasonable with the bilinear interpolation method $(\mathrm{Cp}>0)$, but the results of the nearest grid point selection do not indicate that they are reasonable $(\mathrm{Cp}<0)$. Therefore, the comparisons with the bilinear method will be discussed only.

As it is expected, related with the complex topography of Turkey, a visual comparison of 12 hourly NNRP and observation data time series for 
eight stations of Turkey indicate that each location has own uncertainty due to local meteorological effects (Figure 2). A general evaluation may suggest that observations of Adana (a) and Samsun (h) stations do not agree with the NNRP model. Similarly, NNRP model cannot capture the highest precipitable water $(\mathrm{PW})$ values observed in the beginning of 2015 for six stations. Generally, if local effects dominate PW amount more than that of mesoscale or large scale perturbations, then the accuracy of NNRP is reduced due to the fact that the resolution of the model is not high enough to resolve those local effects. On the other hand, a periodicity that observed in radiosonde time series for all stations due to seasonality is also inspected in NNRP time series for the corresponding locations.

Table 1. Error estimations and Goodness of fit measures between NNRP and radiosonde data for 8 stations of Turkey (Bilinear Interpolation is indicated by Bilinear and Nearest Grid Point Value is indicated by Nearest in the related columns)

\begin{tabular}{lrrrrrrrrrr}
$\begin{array}{l}\text { Station } \\
\text { Name }\end{array}$ & $\begin{array}{c}\text { MAE (mm) } \\
\text { Bilinear Nearest }\end{array}$ & \multicolumn{2}{c}{$\begin{array}{c}\text { RMSE (mm) } \\
\text { Bilinear Nearest }\end{array}$} & \multicolumn{2}{c}{$\begin{array}{c}\text { NRMSE (\%) } \\
\text { Bilinear Nearest }\end{array}$} & \multicolumn{2}{c}{$\begin{array}{c}\text { Cp } \\
\text { Bilinear Nearest }\end{array}$} & \multicolumn{2}{c}{$\begin{array}{c}\text { PBIAS (\%) } \\
\text { Bilinear Nearest }\end{array}$} \\
\hline Adana & $\mathbf{7 . 5 6}$ & $\mathbf{8 . 5 5}$ & $\mathbf{9 . 3 0}$ & $\mathbf{1 0 . 0 9}$ & $\mathbf{1 3 . 8}$ & $\mathbf{1 5}$ & $\mathbf{- 2 . 3 2}$ & $\mathbf{- 2 . 9 1}$ & $\mathbf{- 3 4 . 3 0}$ & $\mathbf{- 3 8 . 9 0}$ \\
Ankara & 2.04 & 2.08 & 2.60 & 2.66 & 6.9 & 7.1 & 0.45 & 0.42 & -12.50 & -12.80 \\
Diyarbakir & 1.91 & 1.90 & 2.79 & 2.78 & 4.5 & 4.4 & 0.50 & 0.50 & -7.60 & -7.40 \\
Erzurum & 1.73 & 1.68 & 2.79 & 2.65 & 4.3 & 4.1 & 0.40 & 0.46 & 10.50 & -1.10 \\
Isparta & 1.39 & 1.57 & 1.95 & 2.14 & 4.7 & 5.1 & 0.67 & 0.60 & 5.70 & 7.30 \\
Istanbul & 3.18 & 4.80 & 4.42 & 6.09 & 8.2 & 11.2 & 0.05 & $\mathbf{- 0 . 8 1}$ & -11.80 & -22.70 \\
Izmir & 2.28 & 2.69 & 3.25 & 3.62 & 5.4 & 6 & 0.44 & 0.30 & -9.10 & -11.50 \\
Samsun & $\mathbf{5 . 4 2}$ & $\mathbf{8 . 8 6}$ & $\mathbf{6 . 6 6}$ & $\mathbf{1 0 . 0 3}$ & $\mathbf{1 3 . 8}$ & $\mathbf{2 0 . 7}$ & $\mathbf{- 1 . 4 9}$ & $\mathbf{- 4 . 6 3}$ & $\mathbf{- 2 5 . 4 0}$ & $-\mathbf{4 1 . 8 0}$ \\
\hline
\end{tabular}

Discrepancies which are revealed in the visual inspections of time series are quantified by means of five goodness of fit tests (Table 1). The Coefficient of Persistence (Cp) values of interested locations are evaluated first because $\mathrm{Cp}$ values are the first threshold in accepting the model performance. If $\mathrm{Cp}$ values are smaller than 0.0 then it is assumed that the model performance is not acceptable for further evaluation. In accordance with the visual evaluations of time series, Cp values of six stations indicate that they passed the threshold test except for Adana and Samsun observation locations (indicated by bold characters in Table 1.) where Cps are smaller than 0.0 and, thus, NNRP model performance for these stations are not acceptable without applying any bias correction method. MAE and RMSE values presented in the second and fourth column of Table 1 , indicate fairly small errors. On the other hand, RMSEs of six stations, range between $1.95 \mathrm{~mm}$ and $4.42 \mathrm{~mm}$, may not be considered small enough when they compare to the NNRP performance against sonde stations of the United States [8] whose RMSE range is between $0.5 \mathrm{~mm}$ and 1.2 $\mathrm{mm}$, according to the Table 1 of this study.

PBIAS values of acceptable stations (Ankara, Diyarbakir, Erzurum, Isparta, Istanbul, and Izmir) mostly indicate a negative bias, except for Erzurum and Isparta (The tenth column of Table 1). This means that NNRP model tends to underestimate PW quantities being consistent with the corresponding time series (Figure 2). The reason of this underestimation might be related with the horizontal resolution of the model and, thus, local moisture effects observed in radiosonde data may not be captured by the model. NNRP model shows a positive bias for Erzurum and Isparta because the PW rates of this cities are the lowest (Figure 2) due to the fact that they are located at higher elevations than others. 
Table 2. Mean values of NNRP and radiosonde data for 8 stations of Turkey with the number of missing values in observations

\begin{tabular}{lccc}
\hline Station Name & PW-NNRP (mm) & PW-Observed (mm) & Missing Values [\#/2192] \\
Adana & $\mathbf{1 4 . 4 2}$ & $\mathbf{2 1 . 8 7}$ & $\mathbf{3 4}$ \\
Ankara & 12.22 & 13.97 & 11 \\
Diyarbakir & 13.01 & 14.07 & 20 \\
Erzurum & 13.97 & 9.14 & 42 \\
Isparta & 14.18 & 13.43 & 8 \\
Istanbul & 17.33 & 19.65 & 12 \\
Izmir & 17.53 & 19.30 & 16 \\
Samsun & $\mathbf{1 5 . 7 8}$ & $\mathbf{2 1 . 1 8}$ & $\mathbf{1 9}$ \\
\hline
\end{tabular}

The reasons of variations in the goodness of tests depending on the location may better be seen in probability density functions (PDF) of NNRP and radiosonde data for each location (Figure 3). In Figure 3, black PDFs show observations, whereas blue lines are for NNRP distributions. The black and blue vertical lines are the mean values (Table 2.) for observations and NNRP, respectively (Table 2).
Figure 3. implies that PW distributions of NNRP and observations do not agree for Adana and Samsun, as detected with time series evaluations and GoF calculations. The negative bias of NNRP data for 4 stations (Ankara, Diyarbakir, Istanbul, and Izmir) is approved with PDFs. It is important to note that although distributions are quite similar for 6 stations, their tails demonstrate that NNRP model cannot simulate extreme values for all stations. 

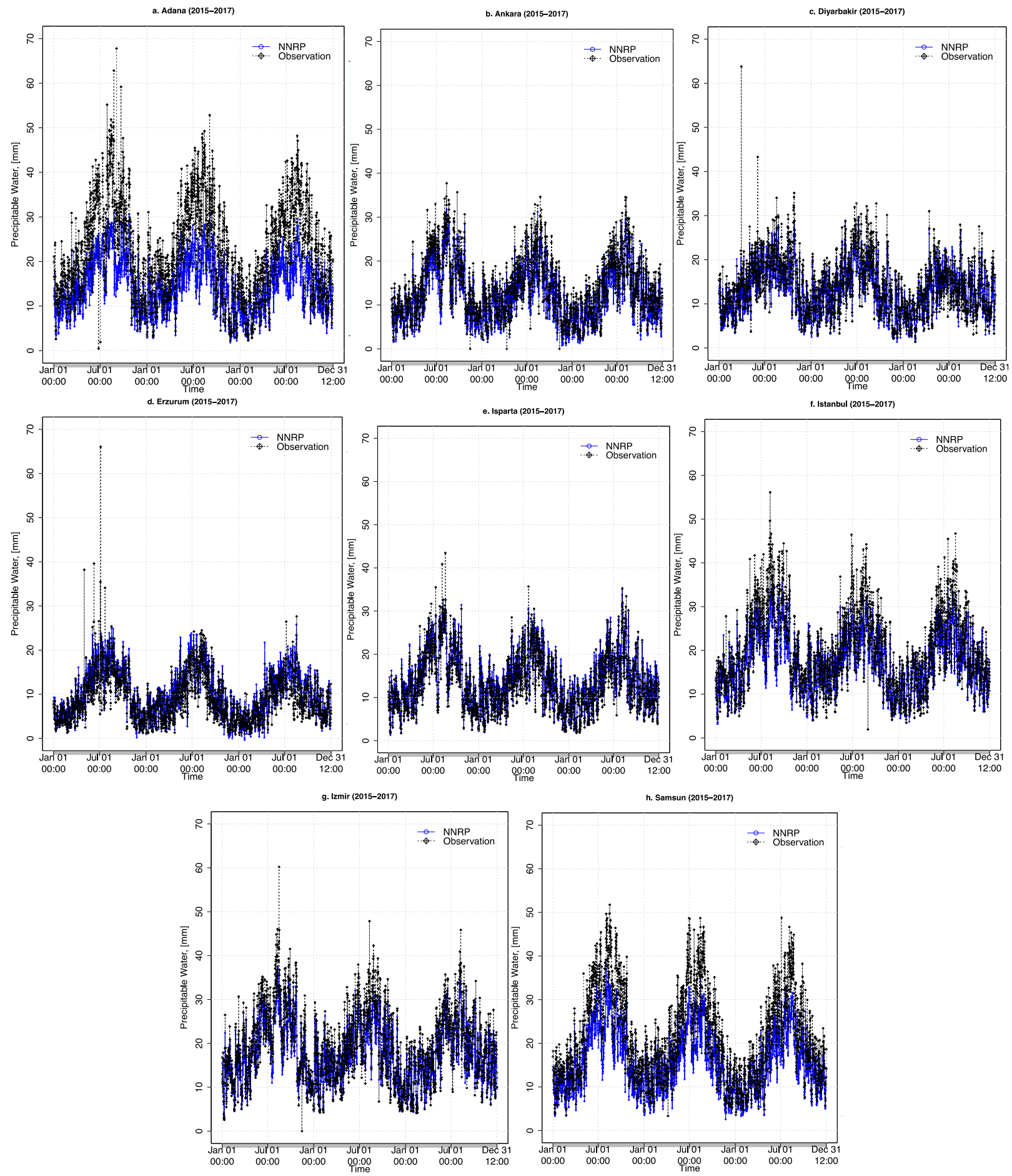

Figure 2. Precipitable Water Time Series Comparisons of NNRP data and radiosonde observations for eight stations of Turkey. 

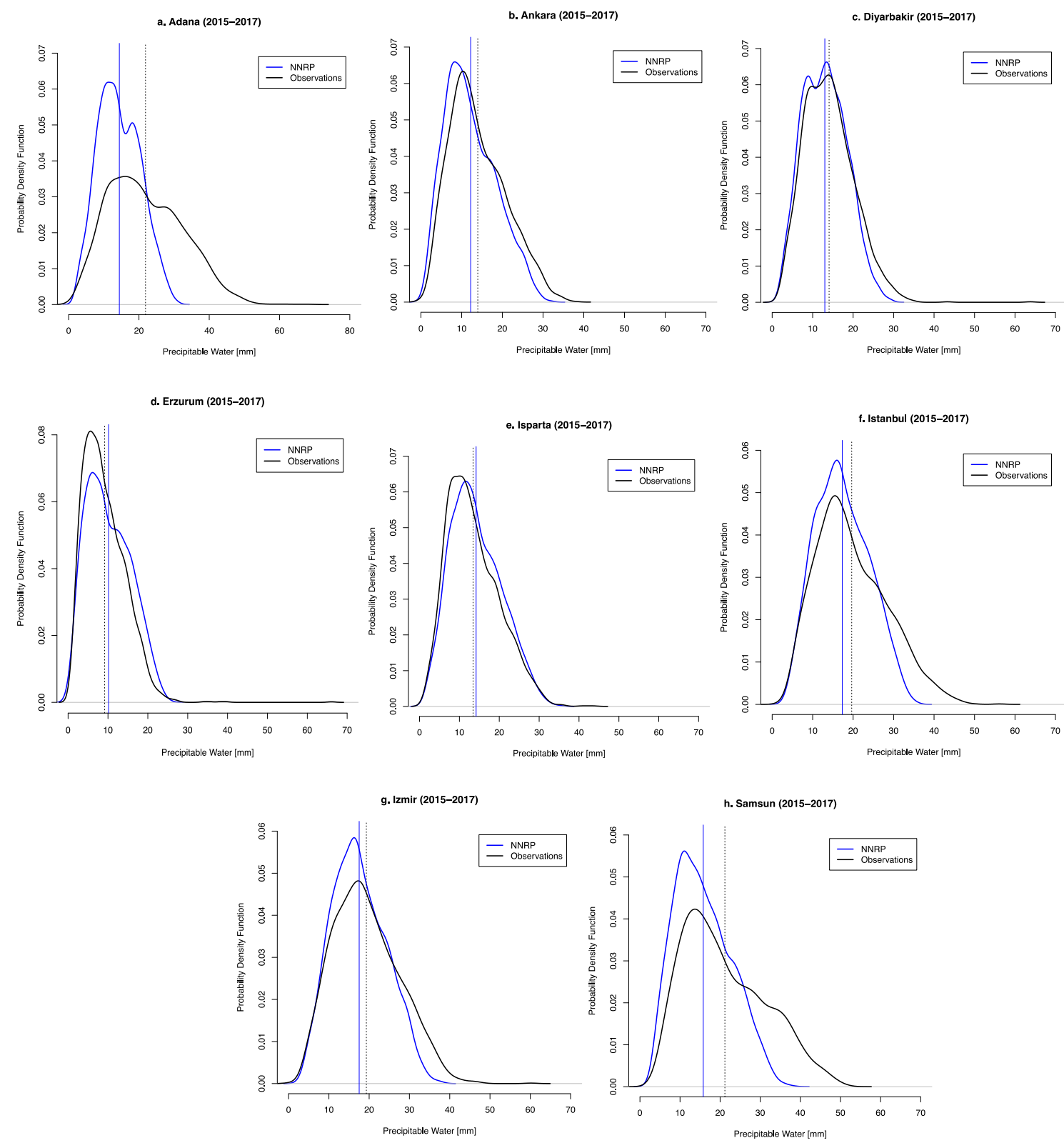

Figure 3. Probability density functions of NNRP data and radiosonde observations for 8 stations of Turkey between 2015 and 2017. Vertical lines indicate mean values of NNRP data (blue) and observations (black).

\section{CONCLUSION}

12-hourly Precipitable Water (PW) comparisons between NNRP data and radiosonde profiles clearly indicate that NNRP model may not capture local effects especially for the extreme PW values for Turkey. The local effects might be included to the data by applying some observational assimilation techniques or simulating the same conditions, i.e. hindcasting, with a higher resolution atmospheric model, such as the Weather Research and Forecasting Model (WRF). NNRP model results are not acceptable for the coastal cities Adana and Samsun where local moisture sources are dominant. NNRP model also produces more PW values for Erzurum where the station is located at high elevation with less moisture. NNRP data is more reliable for inland cities where moisture sources are dependent upon mesoscale effects which is consistent with the findings of [8] 
that the data might have more error for mountainous regions. NNRP model tends to underestimate PW values for Turkey, except Isparta and Erzurum which are located inland and at higher elevations. Time series of radiosonde observations clearly show the diurnal and seasonal variations of $\mathrm{PW}$ whose values are greater during summer months than winter due to the fact that water vapor transport capacity of air depends entirely on the temperature. This periodicity and the order of magnitudes of PW for Istanbul, Izmir, and Ankara are consistent with the distributions of monthly precipitable water amounts estimated by [16] for the period of 1974 and 1984. As a result, NNRP data should be utilized after checking its consistency with observations for the interested regions of Turkey. These results imply that a subset reanalysis data of NNRP should be constructed for Turkey by assimilating remote sensing system, especially for climate change related studies.

\section{ACKNOWLEDGMENTS}

Ali Hasan Tan is kindly acknowledged for his valuable discussions and 2 anonymous reviewers are contributed to improving the manuscript with their constructive comments.

\section{REFERENCES}

[1] Precipitable water, Glossary of Meteorology, American Meteorological Society, http://glossary.ametsoc.org/wiki/Precipitable_ water. Accessed: 29 Jan 2018.

[2] Kalnay E., Kanamitsu M., Kistler R., Collins W., Deaven D., Gandin L., Iredell M., Saha S., White G., Woollen J., Zhu Y., Chelliah M., Ebisuzaki W., Higgins W., Janowiak J., Mo K.C., Ropelewski C., Wang J., Leetmaa A., Reynolds R., Jenne R. and Joseph D., The NCEP/NCAR 40-year reanalysis project. Bull. Amer. Meteor. Soc., 77 (1996) 437-471.

[3] Xie P. and Arkin P.A., Global precipitation: A 17-year monthly analysis based on gauge observations, satellite estimates, and numerical model outputs. Bulletin of the American Meteorological Society, 78 (1997) 2539-2558.

[4] Trenberth K.E. and Guillemot C.J., Evaluation of the atmospheric moisture and hydrological cycle in the NCEP/NCAR reanalyses, Clim Dyn, 14 (1998) 213-231.

[5] Bromwich D.H., Fogt R. L., Hodges K. I. and Walsh J. E., A tropospheric assessment of the ERA-40, NCEP, and JRA-25 global reanalyses in the polar regions, J. Geophys. Res., 112 (2007) D10111.

[6] Ma L., Zhang T., Frauenfeld O.W., Ye B., Yang D. and Qin D., Evaluation of precipitation from the ERA-40, NCEP-1, and NCEP-2 Reanalyses and CMAP-1, CMAP-2, and GPCP-2 with ground-based measurements in China, Journal of Geophysical Research, 114 (2009) D09105. https://doi.org/10.1029/2008JD011178.

[7] Sun Q., Miao C., Duan Q., Ashouri H., Sorooshian S. and Hsu K.-L., A review of global precipitation data sets: Data sources, estimation, and inter- comparisons. Reviews of Geophysics, 56 https://doi.org/10.1002/2017RG000574.

[8] Trenberth K.E., Fasullo J. and Smith L., Trends and variability in column integrated atmospheric water vapor. Climate Dyn., 24, 7 8 (2005) 741-758.

[9] Fistikoglu O. and Okkan U., Statistical downscaling of monthly precipitation using NCEP/NCAR reanalysis data for Tahtali River basin in Turkey, ASCE J Hydrol Eng, 16(2) (2011) 157-164.

[10] Tatli H., Statistical complexity in daily precipitation of NCEP/NCAR reanalysis over the Mediterranean basin. Int. J. Climatol., 34 (2014) 155-161.

[11] Bozkurt D., Turuncoglu U., Sen O.L., Onol B. and Dalfes H.N., Downscaled simulations of the ECHAM5, CCSM3 and HadCM3 global models for the eastern Mediterranean-Black Sea region: evaluation of the reference period, Clim Dyn, 39-1,2 (2012) 207-225.

[12] National Centers for Environmental Prediction/National Weather Service/NOAA/U.S. Department of Commerce. 1994, updated monthly. NCEP/NCAR Global Reanalysis Products, 1948-continuing. Research Data Archive at the National Center for Atmospheric Research, Computational and Information Systems Laboratory. 
http://rda.ucar.edu/datasets/ds090.0/.Accessed:

28 JAN 2018.

[13] University of Wyoming, College of Engineering, Upper Air Radiosonde Data. http://weather.uwyo.edu/upperair/sounding.ht ml. Accessed: 28 JAN 2018.

[14] Turkish State Meteorological Service, Statistics Report of Relative Humidty, https://www.mgm.gov.tr/FILES/resmiistatistikler/Turkiye-Ortalama-Nem.pdf. Accessed: 1 FEB 2018.

[15] Mauricio, Z.-B., hydroGOF: Goodness-of-fit functions for comparison of simulated and observed hydrological time series. $\mathrm{R}$ package version $\quad 0.3-10 . \quad$ http://CRAN.Rproject.org/package=hydroGOF, (2017).

[16] Topcu, S. Atmosferdeki Yağışa Geçebilir Su Buharı Miktarının Hesaplanması, Coğrafya Araştırmaları Dergisi, Cilt 1, Say1 1 (1989). In Turkish. Accessed 1 FEB 2018. http://tucaum.ankara.edu.tr/wpcontent/uploads/sites/280/2015/08/cadata1_9.p df 